\title{
KRITERIA 29: CARA PANDANG BARU DALAM PENYUSUNAN KALENDER HIJRIYAH
}

\author{
Hendro Setyanto \\ Observatorium Imah Noong, Kampung Areng Wangunsari Lembang \\ e-mail:setyanto@gmail.com
}

\section{Fahmi Fatwa Rosyadi Satria Hamdani}

Universitas Islam Bandung

email: fatwa19@unisba.ac.id

\begin{abstract}
Hilāl is an early marker of the beginning of the Hijriyah/Qamariyah. The existence of the new moon was used as a reference in the preparation of a system of Islamic calendar. The issue of the new moon it is still be an interesting thing to be studied. In fact there is a lot of research and discussion related with hilāl issues. However, it still has not found an appropriate formula to be used as a reference in creating a standardized system of the Islamic calendar. Currently, there are several criteria that offered to make the calendar system. In this paper, will be presented criteria and other perspectives in formulating a Hijriyah calendar, called the Criteria 29. Some examples of simple calculations and discussions in determining the first day of month of the Hijriyah presented briefly. This elaboration of "Criteria 29" hopefully can give an idea and different viewpoints in order to develop Hijriyah calendar.
\end{abstract}

\section{[}

Hilāl merupakan penanda dimulainya awal bulan Hijriyah/Qamariyah. Keberadaan hilāl pun dijadikan acuan dalam penyusunan sebuah sistem penanggalan Islam. Persoalan hilāl memang hingga saat ini masih menjadi hal yang menarik untuk selalu dikaji. Bahkan terdapat banyak penelitian dan pembahasan yang terus dilakukan terkait persoalan hilāl. Namun, masih belum ditemukan formula yang dinilai tepat untuk dijadikan acuan dalam membuat suatu sistem penanggalan Islam yang baku. Saat ini, sudah terdapat beberapa kriteria yang ditawarkan untuk membuat sistem penanggalan tersebut. Dalam tulisan ini, akan dipaparkan kriteria atau cara pandang lainnya dalam menyusun sebuah kalender Hijriyah, yaitu Kriteria 29. Beberapa contoh perhitungan dan pembahasan sederhana dalam menentukan tanggal satu bulan Hijriyah disampaikan secara ringkas, dengan harapan Kriteria 29 ini dapat memberikan gambaran dan cara pandang yang lain dalam upaya menyusun sebuah kalender Hijriyah.

Keywords: hilāl, penanggalan Islam, kriteria, Kriteria 29, Kalender Hijriyah 
Hendro Setyanto \& Fahmi Fatwa Rosyadi Satria Hamdani

\section{Pendahuluan}

Penanggalan, yang kini dikenal dengan istilah kalender merupakan salah satu mahakarya umat manusia dalam mempelajari dan memanfaatkan keteraturan gerak alam (Matahari, Bulan dan bintang). Pada umumnya penanggalan digunakan untuk keperluan penataan waktu hidup umat manusia. Adanya penanggalan, telah membantu manusia agar dapat mencatat fenomena dan peristiwa besar yang terjadi pada dirinya. Meskipun pada dasarnya kemunculannya lebih dikarenakan kebutuhan manusia untuk beribadah pada Zat yang memiliki kekuatan besar di luar dirinya yang disebut Tuhan.

Berdasarkan benda langit yang dijadikan dasar perhitungan, sistem penanggalan dapat dikelompokkan menjadi 3 yaitu: ${ }^{1}$ 1) Solar Calendar (Kala Surya), yang didasarkan pada pergerakan Matahari mengelilingi Bumi, seperti kalender Gregorian yang saat ini telah diberlakukan secara internasional. 2) Lunar Calendar (Kala Candra), yang didasarkan pada pergerakan Bulan mengelilingi Bumi, seperti yang digunakan pada kalender Islam dan Jawa. 3) Lunisolar Calendar (Kala Surya-Candra), yang didasarkan pada pergerakan Matahari dan Bulan dalam mengelilingi Bumi, seperti yang digunakan pada kalender Cina, Yahudi, dan kalender yang berkembang di sekitar Jazirah Arab sebelum Islam datang. 2

Penanggalan Hijriyah yang digunakan saat ini didasarkan pada pergerakan Bulan mengelilingi Bumi. Namun, penanggalan Hijriyah tersebut belum menemukan tata aturan baku yang dapat diterima oleh semua pihak. Hal ini

\footnotetext{
${ }_{1}^{1}$ Nachum Dershowitz dan Edward M. Reingold, Calendrical Calculations (New York: Cambridge University Press, 1997), h. 33, 63, dan 85; lihat juga Muh. Nashirudin, Kalender Hijriyah Universal: Kajian atas Sistem dan Prospeknya di Indonesia (Semarang: El-Wafa, 2013), h. 28.

${ }^{2}$ Mohammad Ilyas, seorang ahli astronomi Islam dari Malaysia, menjelaskan bahwa sistem penanggalan yang didasarkan pada pergerakan Bulan memiliki keunggulan jika dibandingkan dengan Matahari. Pasalnya, penggunaan Bulan sebagai penentuan waktu kalender cukup sederhana dan hanya menggunakan alat bantu yang mudah namun akurat. Oleh karenanya, menurut sejarah bangsa-bangsa di kawasan Timur Tengah (Babylon, Yunani, Yahudi, dan Mesir), Barat (Aztec dan Inca), dan Timur (China dan Hindu), pada mulanya menggunakan sistem Lunar Calendar meskipun pada akhirnya menggunakan sistem Lunisolar Calendar pada sistem penanggalan kalender mereka. Lihat Mohammad Ilyas, Sistem Kalendar Islam dari Perspektif Astronomi (Kuala Lumpur: Dewan Bahasa dan Pustaka, 1997), h. 4.
} 
terjadi karena penanggalan Hijriyah tidak hanya difungsikan untuk kebutuhan administrasi negara sebagaimana yang terjadi pada zaman khalifah Umar bin Khatab, ${ }^{3}$ melainkan juga difungsikan sekaligus sebagai kalender ibadah.

\section{Sekilas Sejarah Penanggalan Hijriyah}

Sebelum peristiwa haji Wada' yang dilaksanakan oleh Nabi dan kaum Muslimin, sistem penanggalan masyarakat Arab di Makkah ketika itu masih menggunakan konsep al-Nasī’. Keberadaan istilah waktu al-Nasī’ tersebut telah mempersulit untuk merunutkan fenomena/peristiwa yang terjadi sebelum haji Wada'. Hal ini dikarenakan aturan penggunaan waktu al-Nasī’ tidak berjalan dengan baik. Bangsa Arab dikenal sering memundur dan memajukan kegiatan-kegiatan yang dilakukan pada bulan-bulan Haram sesuai dengan kebutuhannya. ${ }^{4} \mathrm{Hal}$ inilah yang menjadikan penanggalan masyarakat Arab sebelum Haji Wada' dapat dikatakan tidak konsisten. Firman Allah dalam QS. al-Taubah [9]: 36-37,

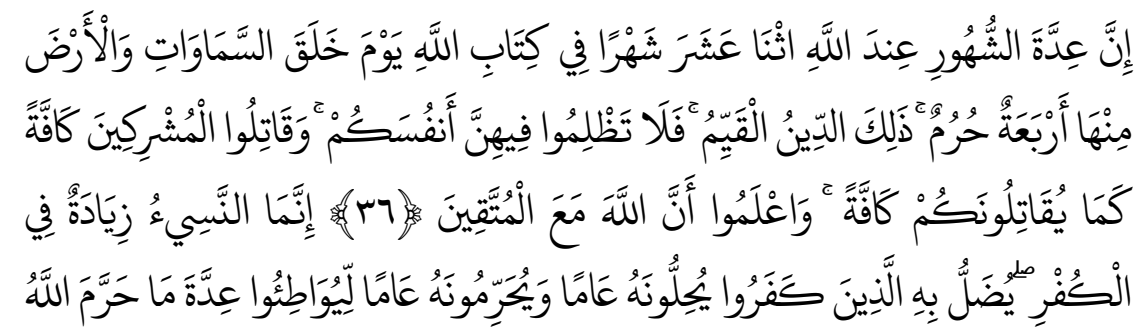

3Pada zaman khalifah Umar bin Khațtab, pembagian jumlah hari pada bulan Hijriyah yang ganjil adalah 30 hari, sedangkan bulan Hijriyah yang genap adalah 29 hari. Pembagian jumlah hari dalam hal ini terkait dengan urusan administrasi pemerintahan khalifah pada saat itu. Di mana sistem perhitungan yang digunakan dikenal dengan istilah hisab urfi. Untuk lebih memperdalam pemahaman lihat Țanțawi Jauharī, al-Jawāhir fi Tafsìr al-Qur'ān, juz 6 (Mesir: Musțafā al-Bābī al-Halbī, 1928), h. 17. Baca juga Muhyiddin Khazin, Ilmu Falak dalam Teori dan Praktik (Yogyakarta: Buana Pustaka, 2004), h. 110-111.

${ }^{4}$ Bulan-bulan Haram yang dimaksud adalah Zulkaidah, Zulhijah, Muharam dan Rajab. Masyarakat Arab ketika itu sering melanggar aturan yang telah ditetapkan. Terkadang mereka mengadakan peperangan di bulan-bulan Haram tersebut dengan mengadakan peperangan, dan menjadikan bulan Safar sebagai bulan yang disucikan/dihormati pengganti bulan Muharam (karena melakukan peperangan di bulan Muharam). Hal ini tidak hanya berdampak pada waktu ibadah mereka saja, namun juga berdampak pada tata tertib serta laju perdagangan di Jazirah Arab menjadi terganggu. Penjelasan lebih lengkap lihat Țanțawi Jauharī, al-Jawāhir fi Tafsīr al-Qur'ān, juz 5 (Mesir: Musțafā alBābī al-Ḥalbī, 1928), h. 95-96. 
Hendro Setyanto \& Fahmi Fatwa Rosyadi Satria Hamdani

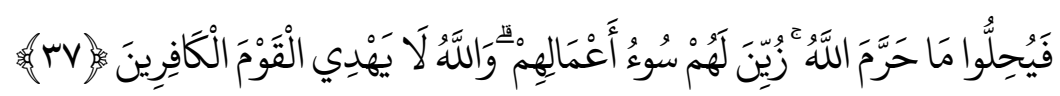

(36) Sesungguhnya bilangan bulan pada sisi Allah ialah dua belas bulan, dalam ketetapan Allah di waktu Dia menciptakan langit dan bumi, di antaranya empat bulan haram. Itulah (ketetapan) agama yang lurus, maka janganlah kamu menganiaya diri kamu dalam bulan yang empat itu, dan perangilah kaum Musyrikin itu semuanya sebagaimana merekapun memerangi kamu semuanya; dan ketahuilah bahwasanya Allah beserta orang-orang yang bertakwa. (37) Sesungguhnya mengundur-undurkan bulan haram itu adalah menambah kekafiran, disesatkan orang-orang yang kafir dengan mengundurundurkan itu, mereka menghalalkannya pada suatu tahun dan mengharamkannya pada tahun yang lain, agar mereka dapat mensesuaikan dengan bilangan yang Allah mengharamkannya maka mereka menghalalkan apa yang diharamkan Allah. (Syaitan) menjadikan mereka memandang baik perbuatan mereka yang buruk itu. Dan Allah tidak memberi petunjuk kepada orangorang yang kafir."5

Maksud dari istilah waktu al-Nasī’ (waktu pengunduran) adalah diundurnya waktu untuk melaksanakan suatu kegiatan pada waktu tertentu. Salah satunya adalah pengunduran waktu ibadah haji oleh masyarakat Arah ketika itu. Mereka terkadang melaksanakan ibadah haji pada waktunya, terkadang pula pada bulan Muharam, Safar, dan bulan-bulan lainnya di antara dua belas bulan. Dampaknya, adalah kegiatan mereka yang biasanya dilakukan pada bulan-bulan haram menjadi terabaikan. Hal ini dikarenakan pada saat mereka sedang melaksanakan ibadah haji, mereka bertemu dengan pembunuh ayah mereka, atau bertemu dengan pembunuh sanak saudara mereka, yang menyebabkan mereka membalas dendam pada waktu tersebut. Padahal Allah telah menerangkan bahwa melakukan amalan-amalan saleh pada bulan-bulan tersebut merupakan sebesar-besarnya pahala. Sebaliknya, perbuatan zalim yang dilakukan pada saat itu seburuk-buruknya kesalahan, bahkan menambah kekafiran. ${ }^{6}$

Namun demikian, konsep al-Nasī’ dimaksudkan untuk menyesuaikan fase Bulan dengan perubahan musim yang diakibatkan oleh posisi dan gerak Matahari di Jazirah Arab.7 Sehingga dapat dikatakan penanggalan masyarakat Arab ketika itu termasuk menggunakan sistem Penanggalan Matahari-Bulan

\footnotetext{
${ }^{5}$ QS. al-Taubah [9]: 36-37.

6Tanțawi, al-Jawāhir, juz 5, h. 95-96.

${ }^{7}$ Nashirudin, Kalender Hijriyah, h. 35.
} 
(Kala Surya-Chandra). Meski demikian, Nabi Muhammad beserta umat Islam ketika itu mengikuti kalender yang berjalan. Sehingga dapat dikatakan seluruh hidup Nabi Muhammad berpuasa dalam sistem penanggalan yang ditetapkan oleh bangsa Quraisy. Nabi tidak membuat sistem penanggalannya sendiri. Akan tetapi, untuk keperluan ibadah Nabi Muhammad memberikan panduan seperti yang sudah umum dikenal dalam sabdanya:

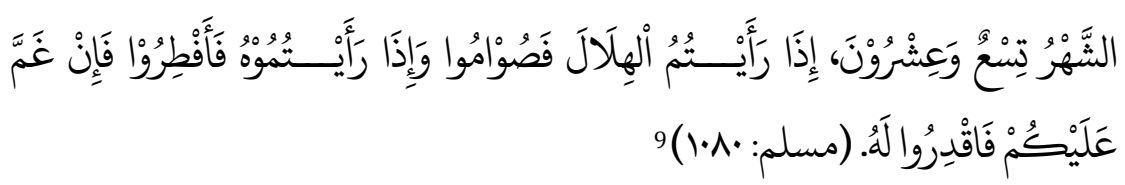

Bulan itu dua puluh sembilan hari, jika kamu melihat hilāl maka berpuasalah dan jika kamu melihatnya (hilāl) maka akhirilah, jika ada mendung menutupi kalian, maka hitunglah.

Turunnya QS. al-Taubah [9]: 36-37, yang melarang penggunaan yaum alNasi' (waktu pengunduran) telah mengubah sistem penanggalan masyarakat Arab dari sistem Lunisolar Calendar menjadi sistem Lunar Calender. Inilah yang menjadi awal mula atau kelahiran sistem penanggalan Islam yang berbasis pada pergerakan Bulan dalam mengelilingi Bumi. Hingga saat ini belum diketahui dengan baik bagaimana praktek penanggalan Islam pada zaman sahabat. Namun, diyakini penanggalan Islam pada masa itu didasarkan pada kesaksian ru'yat al-hiläl. Adapun proses bagaimana praktek penanggalan Hijriyah sejak berubahnya sistem penanggalan tersebut pada dasarnya dapat ditelusuri melalui kajian sejarah, sebagaimana yang telah dilakukan oleh Saleh al-Saab dari King Abdul'aziz City for Science and Technology (KACST), Riyadh. ${ }^{9}$

Praktek penanggalan Islam kemudian disempurnakan melalui konsep penanggalan yang dirumuskan pada zaman Umar bin Khatțab. Melalui sidang para sahabat, ditetapkanlah perhitungan tahun dalam penanggalan kekhalifahan, dimulai sejak hijrahnya Nabi Muhammad dari Mekkah ke Madinah.10

\footnotetext{
${ }^{8}$ Abī Husain Muslim, Șaḥịh Muslim (Riyadh: Dār al-Ṭayyibah, 2006), h. 482.

${ }^{9}$ Komunikasi dilakukan oleh penulis secara langsung dengan Dr. Saleh al-Saab pada tahun $2014 \mathrm{di}$ Bandung.

${ }^{10}$ G.S.P. Freeman Grenville, The Muslim and Christian Calendars (New York: Oxford University Press, 1963), h. 1.
} 
Penetapan tahun hijrahnya Nabi sebagai tahun pertama tersebut merupakan usulan dari Sahabat 'Ali bin Abī Tāāib.11 Oleh karena itu, penanggalan kekhalifahan Islam dikenal sebagai penanggalan Hijriyah, dengan bulan Muharam sebagai bulan pertama dalam penanggalan tersebut. Hal tersebut telah umum berlaku di masyarakat Arab ketika itu.

Sama halnya dengan penanggalan Masehi yang digunakan saat ini, penanggalan Hijriyah pun pada zaman sahabat ditetapkan berdasarkan perhitungan matematis. Jumlah hari yang digunakan senantiasa tetap setiap bulannya. Walaupun demikian, hal-hal yang terkait dengan pelaksanaan ibadah kaum Muslimin ketika itu tetap mengikuti ketentuan yang telah diajarkan oleh Nabi Muhammad. Oleh karenanya, penanggalan Hijriyah yang telah ditetapkan merupakan penanggalan Administrasi Negara.

Seiring dengan perkembangan pemahaman dan pengetahuan, saat ini fungsi penanggalan Hijriyah sebagai penanggalan sosial menjadi satu kesatuan dengan fungsinya sebagai penanggalan ibadah. Hal inilah yang dilihat secara subyektif oleh penulis sebagai kisruh sistem penanggalan Hijriyah. Maka dari itu, untuk mengurai permasalahan pada tahap awal adalah dengan melepaskan fungsi ibadah dari sistem penanggalan Hijriyah. Namun, aturan ibadah tetap menjadi dasar dalam penyusunan kalender Hijriyah, sebagaimana yang telah dipraktekkan oleh sahabat. Adapun proses pencapaian kesatuan dalam beribadah, dapat diawali dengan menyepakati penggunaan kalender tunggal yang digunakan bersama, sedangkan pelaksanaan ibadah dikembalikan kepada masing-masing.

\section{Ijtimā' dan Awal Bulan}

Pemahaman mengenai penentuan awal bulan kamariah perlu memperhatikan kapan terjadi ijtimā'. Fase ini merupakan peralihan dari bulan mati (tanggal akhir bulan) menjadi bulan baru (tanggal awal bulan). Ijtim $\bar{a}^{\prime}$ atau bulan baru (new moon) merupakan peristiwa segaris/sebidangnya pusat

11Khazin, Ilmu Falak, h. 110-111. 
Bulan dan pusat Matahari dari pusat Bumi. Pada peristiwa ini Bulan dan Matahari memiliki bujur ekliptika atau "bujur Astronomi" yang sama. Posisi tersebut ditandai dengan fraksi iluminasi (presentasi penampakan cahaya hilāl terhadap cahaya bulan penuh) minimum. Ijtima $\bar{a}^{\prime}$ berlangsung pada saat yang bersamaan diseluruh permukaan Bumi. Walaupun sering dinyatakan dalam waktu lokal atau waktu setempat. Adanya perbedaan waktu lokal di berbagai tempat dimuka Bumi terjadi akibat perbedaan ketinggian matahari dari pengamat saat berlangsungnya ijtim $\bar{a}^{\prime} \cdot 12$

Pada saat terjadi $i j t i m \bar{a}^{\prime}$ bulan sama sekali tidak tampak dari permukaan bumi, sebab seluruh bagian yang terkena sinar matahari dalam posisi membelakangi bumi, bumi menghadap bulan yang sama sekali tidak terkena sinar matahari, itulah sebabnya pada saat ijtimā' juga biasa disebut bulan mati. ${ }^{13}$

Perhitungan ijtimā' memperhatikan beberapa hal berikut:14 1) Menentukan selisih posisi matahari dan bulan saat terbenam matahari pada ekliptika. 2) Menentukan selisih kecepatan tiap jam antara matahari dan bulan pada ekliptika. 3) Selisih posisi dibagi selisih kecepatan ditambahkan kepada saat matahari dan bulan pada ekliptika.

Awal tanggal atau hari dalam penanggalan matahari (Syamsiyah) berlangsung pada saat posisi Matahari mencapai titik kulminasi bawah, berlangsung pada jam 00.00 atau jam 24.00 waktu setempat. Sedangkan awal bulan (new month) menjadi penanda awal penanggalan (tanggal 1) bulan Hijriyah. Hal tersebut berlangsung pada tanggal dimulai saat Matahari terbenam (ghurūb), dan awal bulan Qamariyah tergantung pada posisi hiläl pada tanggal 29 bulan Hijriyah yang sedang berjalan. ${ }^{15}$ 1) Jika pada saat ghurūb tanggal 29 bulan Hijriyah, posisi bulan belum mencapai ijtimā' secara astronomis, maka bulan yang sedang berjalan berumur 30 hari, atau keesokan harinya masih berada dibulan yang sedang berjalan. 2) Jika pada saat ghurūb tanggal

\footnotetext{
12Vivit Fitriyani, Penerapan Ilmu Astronomi dalam Upaya Unifikasi Kalender Hijriyah di Indonesia, Makalah untuk Annual Conference on Islamic Studies (ACIS) ke-12 Tahun 2012 di Surabaya h. 23

13Ibid,, h. 23.

14 I Ibid, h. 23-24.

15 Ibid., h. 25.
} 
29 bulan Hijriyah $\ddot{i j t i m a ̄ '}$ sudah terjadi, posisi hilāl terhadap Matahari negatif atau hilāl tebenam lebih dahulu dibanding Matahari, maka umur bulan yang sedang berjalan berumur 30 hari. 3) Jika pada tanggal 29 bulan Hijriyah ijtima $\bar{a}^{\prime}$ sudah terjadi sebelum ghurūb, posisi hiläl positif atau Matahari tenggelam terlebih dahulu dibanding Bulan, maka penentuan awal Bulan berdasarkan kriteria Syari'ah. Jika memenuhi kriteria maka keesokan harinya sudah masuk tanggal 1 bulan baru Hijriyah. Jika belum memenuhi kriteria maka besoknya merupakan tanggal 30 bulan yang sedang berjalan.

Memang dalam beberapa kasus tertentu, tinggi hilāl sudah positif pada saat ghurūb, namun ijtimā' belum terjadi. Hilāl yang berada di atas ufuk pada saat tersebut bukan hilāl awal bulan. Ia merupakan bulan sabit tua menjelang bulan baru atau bulan mati, sehingga keesokan harinya berada pada tanggal 30 bulan yang sedang berjalan. ${ }^{16}$

\section{Kriteria Awal Bulan (Imkān al-Rukyat dan Wujūd al-HilāI)}

Pembahasan mengenai penentuan awal bulan kamariah perspektif ilmu falak adalah dengan menghitung saat terjadinya peristiwa konjungsi atau yang dikenal dengan istilah ijtimā'. Maksudnya adalah ketika posisi Matahari dan Bulan berada pada garis bujur astronomi yang sama. Kemudian setelah itu menghitung posisi Bulan pada saat Matahari terbenam.17 Adapun dasar hukum yang digunakan dalam penentuan awal bulan kamariah di antaranya:

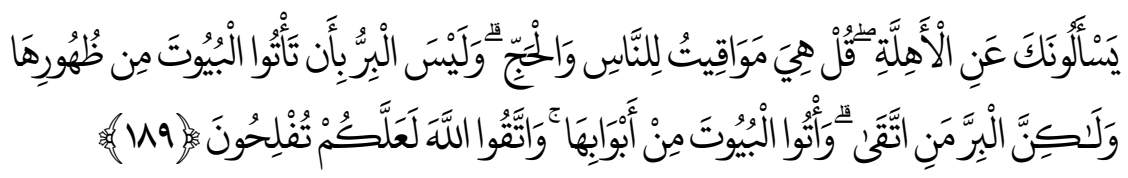

"Mereka bertanya kepadamu tentang bulan sabit. Katakanlah: "Bulan sabit itu adalah tanda-tanda waktu bagi manusia dan (bagi ibadat) haji; dan bukanlah kebajikan memasuki rumah-rumah dari belakangnya, akan tetapi kebajikan itu ialah kebajikan orang yang bertakwa; dan masuklah ke rumah-rumah itu dari pintu-pintunya; dan bertakwalah kepada Allah agar kamu beruntung."18

\footnotetext{
16Ibid.

${ }^{17}$ Ahmad Fauzan, Melacak Algoritma Hisab Awal Bulan Qomariah dalam Kitab Nurul Anwar, Jurnal Penelitian, Vol.11, No. 1, Mei 2004, h. 78.

${ }^{18}$ QS. al-Baqarah [2]: 189. Departemen Agama RI, Syaamil al-Qur'an, h. 29.
} 


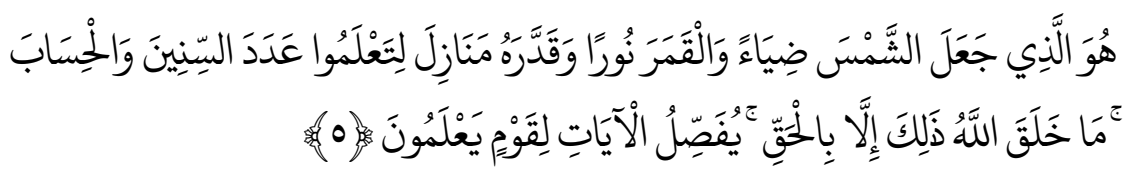

"Dia-lah yang menjadikan Matahari bersinar dan Bulan bercahaya dan ditetapkan-Nya manzilah-manzilah (tempat-tempat) bagi perjalanan bulan itu, supaya kamu mengetahui bilangan tahun dan perhitungan (waktu). Allah tidak menciptakan yang demikian itu melainkan dengan hak (dengan penuh hikmah). Dia menjelaskan tanda-tanda (kebesaran-Nya) kepada orang-orang yang mengetahui."19

Beberapa kriteria tentang penetapan awal bulan yang berkembang di Indonesia di antaranya kriteria imkān al-rukyat, dengan beberapa ketentuan sebagai berikut: 1) Tinggi hilāl tidak kurang dari 5 derajat dari ufuk Barat. 2) Besar sudut elongasi / jarak sudut hilāl ke Matahari tidak kurang dari 8 derajat. 3) Umur hilāl tidak kurang dari 8 jam setelah terjadi konjungsi (ijtimā').

Kriteria tersebut di atas telah disepakati dalam persidangan hilāl negaranegara sedunia di Istanbul Turki tahun $1978 .{ }^{20}$ Namun demikian, beberapa negara di Asia Tenggara yang termasuk dalam lingkup Negara MABIMS seperti Malaysia, Brunei Darussalam, Indonesia, dan Singapura, telah bersepakat untuk menyatukan kriteria dengan menyesuaikan letak geografis tempat. Kriteria yang merupakan gabungan dari kriteria Turki dan hisab-rukyat yaitu: 1) Tinggi hilāl tidak kurang dari 2 derajat, 2) Besar sudut elongasi/jarak sudut hilāl ke Matahari tidak kurang dari 3 derajat, 3) Umur hilāl tidak kurang dari 8 jam setelah terjadi konjungsi (ijtimā'). ${ }^{21}$

${ }^{19}$ QS. Yunus [10]: 5. Departemen Agama RI, Syaamil al-Qur'an, h. 208.

${ }^{20}$ Ahmad Fauzan, Melacak..., h. 80.

21Dalam hal penetapan awal bulan Hijriyah, Noor Ahmad SS (2006) menambahkan bahwa rukyat yang dapat dijadikan dasar penentuan awal Ramadan, Syawal, dan Zulhijah adalah rukyat yang mu'tabar, yaitu rukyat yang dapat dipertanggung jawabkan secara hukum dan ilmiah, dengan persyaratan sebagai berikut: (1) Rukyat dilaksanakan pada saat Matahari terbenam pada malam 30 atau akhir 29 nya; (2) Rukyat dilaksanakan dalam keadaan cuaca cerah tanpa penghalang antara perukyat dan hiläl; (3) Rukyat dilaksanakan dalam keadaan posisi hilāl positif terhadap ufuk (di atas ufuk); (4) Rukyat dilaksanakan dalam keadaan memungkinkan untuk dirukyat (imkān al-ru'yat); (5) Hilăl yang dilihat harus berada di antara wilayat titik Barat antara 30 derajat ke Selatan dan 30 derajat ke Utara; lihat Jayusman, Isyarat Penentuan Awal Bulan Kamariah dalam al-Qur'an: Mencermati Perbedaan Kriteria dan Metode Penetapan Awal Bulan Kamariah di Indonesia, Jurnal alDzikra, Vol. 5, No. 09, Juli-Desember 2011, h. 19-20. 
Adapun kriteria lainnya yang berkembang adalah hisab wujūd al-hilāl. Kriteria ini muncul dari ide salah seorang pakar astronomi Sa'adoeddin Djambek. Azhari menjelaskan dalam penelitiannya sebagaimana dikutip Izzuddin bahwa Sa'adoeddin Djambek adalah tokoh falak modernis dalam bidang hisab yang mencoba memadukan antara hisab dan astronomi modern dengan menggunakan data-data yang cukup valid dan mengikuti perkembangan zaman seperti Almanak Nautika, American Ephemeris, dan Hisab Ephemeris, sehingga data-datanya yang ditampilkan up to date mengikuti perkembangan zaman. ${ }^{22}$ Kriteria ini yang kemudian dikembangkan lagi oleh Muhammad Wardan (1987). Menurutnya, kriteria hisab wujūd al-hilāl adalah Matahari terbenam lebih awal dari terbenamnya Bulan atau dikenal dengan istilah moonset after sunset, meskipun itu terjadi hanya satu menit atau kurang. ${ }^{23}$

Pada prakteknya, awal bulan baru kamariah dinyatakan telah dimulai apabila memenuhi seluruh kriteria sebagai berikut:24 1) Telah terjadi konjungsi (ijtimā'), 2) Konjungsi (ijtimā') terjadi sebelum Matahari terbenam, 3) Pada saat terbenamnya Matahari, piringan atas Bulan berada di atas ufuk (Bulan baru telah wujūd).

Penyimpulan ketiga kriteria tersebut didasari atas pemahaman terhadap firman Allah:

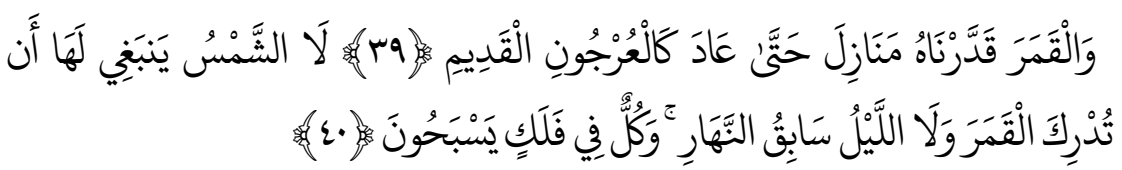

(39) Dan telah Kami tetapkan bagi bulan manzilah-manzilah (tempat-tempat), sehingga (setelah dia sampai ke manzilah yang terakhir) kembalilah dia

\footnotetext{
22Rohmat, Penentuan Awal Bulan Qamariyah menurut Muhammadiyah, Jurnal Ijtimaiyya, Vol. 7, No. 1, Februari 2014, h. 129-130; lihat juga Ahmad Izzuddin, Fiqih Hisab Rukyah: Menyatukan NU \& Muhammadiyah dalam Penentuan Awal Ramadhan, Idul Fitri, dan Idul Adha (Jakarta: Erlangga, 2007), h.124.

${ }^{23}$ Ibid.

${ }^{24}$ Majelis Tarjih dan Tajdid Pengurus Pusat Muhammadiyah, 2009, Pedoman Hisab Muhammadiyah, Yogyakarta: Majelis Tarjih dan Tajdid PP Muhammadiyah, h. 79.
} 
sebagai bentuk tandan yang tua.25 (40) Tidaklah mungkin bagi Matahari mendapatkan Bulan dan malam pun tidak dapat mendahului siang; dan masingmasing beredar pada garis edarnya. ${ }^{26}$

Kedua ayat tersebut memberikan pandangan tentang cara untuk menentukan kriteria bulan baru, karena di dalamnya mengandung tiga hal penting, yaitu:27 1) Peristiwa konjungsi (ijtimā'), 2) Peristiwa pergantian siang ke malam dengan terbenamnya Matahari, 3) Ufuk, karena terbenamnya Matahari terjadi di bawah ufuk, sehingga perlu dilakukan perhitungan untuk mengetahui saat terjadinya ijtimă', saat terbenamnya Matahari, dan juga posisi Bulan saat terbenamnya Matahari.

\section{Kriteria 29}

Fungsi kalender sebagai kalender ibadah menghantarkan para ahli falak sejak dahulu hingga saat ini mengkaji permasalahan kriteria awal bulan. Pada umumnya kriteria awal Bulan yang digunakan mengacu pada masalah visibilitas hilāl yang melibatkan parameter utamanya adalah beda tinggi dan jarak sudutnya terhadap Matahari ketika Matahari terbenam.

Kriteria yang ada selama ini, mencoba melakukan pendekatan awal bulan dengan kriteria visibilitas hilāl yang kondisi visibilitasnya sangat bergantung terhadap kondisi lokal. Lingkungan kepulauan di wilayah ekuator tentu memiliki perbedaan dalam hal visibilitas dengan lingkungan gurun pasir yang berada di wilayah subtropis, Arab Saudi misalnya. Sehingga, upaya untuk menerapkan kriteria visibilitas suatu tempat ke tempat lain tentu memiliki ragam masalah dan kendala.

Di samping itu kriteria visibilitas tidak menjamin akan keberadaan hilāl pada tanggal 29 di bulan Hijriyah, bahkan sering dijumpai hilāl berada di bawah ufuk ketika kegiatan ru'yat al-hilāl pada tanggal tersebut dilaksanakan. Pada mulanya, hal tersebut terasa wajar karena dalam penanggalan Hijriyah

\footnotetext{
25Maksudnya: bulan-bulan itu pada awal bulan, kecil berbentuk sabit, kemudian sesudah menempati manzilah-manzilah, dia menjadi purnama, kemudian pada manzilah terakhir kelihatan seperti tandan kering yang melengkung.

${ }^{26}$ QS. Yāsin [36]: 39-40. Departemen Agama RI, Syaamil al-Qur'an, h. 442.

27Majelis Tarjih..., Pedoman..., h. 79
} 
terdapat konsep istikmal jika hilāl tidak terlihat.28 Namun, jika dipikirkan hal tersebut tampak kurang tepat karena ru'yat al-hilāl menjadi tidak mempunyai fungsi dan terasa aneh. Sebab, masyarakat Muslim tetap melaksanakan rukyat ketika mengetahui hilāl diyakini dengan pasti tidak ada. Oleh karenanya, kriteria yang menjadikan hilāl di bawah ufuk perlu dikaji ulang.

Kriteria 29 merupakan salah satu usulan dalam merumuskan pembuatan sistem penanggalan Hijriyah yang didasarkan pada waktu pelaksanaan ru'yat al-hilāl. Sebagaimana diketahui, adanya kesaksian ru'yat al-hilāl merupakan tanda diawalinya puasa Ramadan. Gagasan dasar dari kriteria ini adalah menetapkan waktu rukyat sebagai tanggal 29 setiap bulannya.

Jika melihat kepada dasar hukum pelaksanaan ru'yat al-hilāl, maka dapat dipastikan bahwa ru'yat al-hilāl dilaksanakan pada tanggal 29 di bulan Hijriyah. Oleh karenanya, perlu didefinisikan bahwa tanggal 29 sebagai hari di mana rukyat dilaksanakan. Rukyat merupakan usaha untuk melihat hilāl. Keberadaan hilāl atau peristiwa konjungsi (ijtimā') merupakan syarat sebagai tanggal 29 pada bulan Hijriyah. Oleh karena hari dalam penanggalan Hijriyah bermula dari tenggelamnya Matahari hingga tenggelam kembali keesokan harinya, ${ }^{29}$ maka dengan Kriteria 29 ini, dapat dipastikan bahwa hilāl tidak akan pernah berada di bawah ufuk.

Setelah menentukan tanggal 29, kita tidak menetapkan tanggal keesokan harinya melainkan menetapkan tanggal sebelumnya. Hal ini dikarenakan

\footnotetext{
${ }^{28}$ Maksud dari istikmal adalah apabila hilāl tidak terlihat pada hari ke-29 di bulan Hijriyah, maka bilangan hari pada bulan tersebut digenapkan menjadi 30. Selengkapnya dapat dilihat Muhyiddin Khazin, Kamus Ilmu Falak (Yogyakarta: Buana Pustaka, 2005), h. 37.

${ }^{29}$ Sebenarnya terdapat dua pendapat mengenai kapan dimulainya hari dalam penanggalan Hijriyah. Pertama, dimulai sejak terjadinya fajar șadiq. Pendapat ini dikemukakan oleh Ibsīm dan alKhanjāri (2006). Mereka berdua adalah ilmuwan di bidang ruang angkasa dan falak dari Lybia. Pendapat yang kedua, dimulai sejak terbenamnya Matahari di ufuk Barat. Pendapat yang kedua ini dikemukakan oleh Zubair Umar al-Jailani, dan ahli falak lainnya seperti Sa'adoeddin Djambek, Slamet Hambali, Muhyiddin Khazin, dan Thomas Djamaluddin. Untuk mendapatkan pemahaman lebih dalam tentang awal dimulainya hari dalam penanggalan Hijriyah, lihat Nashirudin, Kalender Hijriyah, h. 80-82; Ahmad Izzuddin, Fiqih ...., h.124; Susiknan Azhari, Pembaharuan Pemikiran Hisab di Indonesia (Yogyakarta: Pustaka Pelajar, 2002), h. 71-72; Slamet Hambali, Pengantar Ilmu Falak: Menyimak Proses Pembentukan Alam Semesta (Banyuwangi: Bismillah Publisher, 2012), h. 57; dan Thomas Djamaluddin, Menggagas Fiqih Astronomi (Bandung: Kaki Langit, 2005), h. 74.
} 
jumlah hari dalam penanggalan Hijriyah adalah 29 hari atau 30 hari. Dengan kata lain, tanggal 30 boleh ada dan boleh tidak. Sehingga dengan logika sederhana jika tanggal 29 telah ditetapkan maka hari sebelumnya pasti tanggal 28. Keberadaan tanggal 30 ditentukan dengan perhitungan mundur dari bulan setelahnya.

Tabel 1.

Contoh Perhitungan Mundur Penanggalan Hijriyah

\begin{tabular}{|c|c|c|c|c|c|c|c|c|c|c|c|}
\hline \multirow{3}{*}{ Kasus } & \multicolumn{5}{|c|}{ Ramadhan } & \multicolumn{7}{c|}{ Syawal } \\
\cline { 2 - 13 } & Ahad & $\ldots$ & Jumat & Sabtu & Ahad & Senin & Selasa & Rabu & $\ldots$ & Senin & \multirow{2}{*}{ Selasa } \\
\cline { 2 - 13 } & & $\ldots$ & \multicolumn{3}{|c|}{$(1) \ldots \leftarrow$} & \multicolumn{3}{|c}{$\leftarrow \ldots(29)$} & $\ldots$ & & \\
\hline A & 1 & $\ldots$ & 27 & 28 & 29 & 1 & 2 & 3 & $\ldots$ & 29 & \\
\hline B & 1 & $\ldots$ & 27 & 28 & 29 & X & 1 & 2 & $\ldots$ & & 29 \\
\hline
\end{tabular}

Tabel 1 menunjukkan 2 kasus dalam perhitungan mundur penanggalan Hijriyah. Pada kedua kasus (A dan B) tersebut tanggal 29 Ramadhan terjadi pada hari ahad. Dengan kata lain, pada tanggal 29 tersebut hilāl dapat dikatakan wujud. Dengan perhitungan mundur, diperoleh tanggal 1 Ramadhan terjadi pada hari Ahad. Tanggal 29 Syawal pada kasus A terjadi pada hari Senin sehingga dengan hitung mundur akan diperoleh tanggal 1 Syawal terjadi pada hari senin. Karena tanggal 29 Ramadhan terjadi pada hari Ahad, maka tidak terdapat tanggal 30 Ramadhan karena tidak ada hari yang hilang.

Adapun pada kasus B, tanggal 29 Syawal terjadi pada hari Selasa sehingga tanggal 1 Syawal bertepatan dengan hari Selasa. Sehingga terdapat "hari /tanggal" antara tanggal 29 Ramadhan (Ahad) dengan tanggal 1 Syawal (Selasa) yaitu hari Senin tanggal 30 Ramadhan.

Untuk memperjelas konsep perhitungan pada Tabel 1, berikut contoh perhitungan 5 bulan dari Sya'ban-Ramadhan-Syawal-Dzulqa'dah-Dzulhijjah 1435 $\mathrm{H}$ yang dibandingkan dengan perhitungan tanggal dalam penanggalan Masehi. Konsep perhitungan mundur tersebut mengacu pada definisi tanggal 29 adalah Hari Ijtimā'. Penggunaan definisi tersebut untuk memudahkan dalam melihat permasalahan semata. 
Hendro Setyanto \& Fahmi Fatwa Rosyadi Satria Hamdani

Tabel 2.

\section{Simulasi Perhitungan Mundur dalam penanggalan Hijriyah tahun 1435H ${ }^{30}$}

\begin{tabular}{cccccc} 
Tanggal & Sya'ban & Ramadhan & Syawal & Dzulqodah & Dzulhijjah \\
\hline 1 & $29 / 05 / 2014$ & $29 / 06 / 2014$ & $29 / 07 / 2014$ & $27 / 08 / 2014$ & $26 / 09 / 2014$ \\
2 & $30 / 05 / 2014$ & $30 / 06 / 2014$ & $30 / 07 / 2014$ & $28 / 08 / 2014$ & $27 / 09 / 2014$ \\
3 & $31 / 05 / 2014$ & $01 / 07 / 2014$ & $31 / 07 / 2014$ & $29 / 08 / 2014$ & $28 / 09 / 2014$ \\
$\ldots$ & $\ldots$ & $\ldots$ & $\ldots$ & $\ldots$ & $\ldots$ \\
27 & $25 / 06 / 2014$ & $25 / 07 / 2014$ & $24 / 08 / 2014$ & $22 / 09 / 2014$ & $22 / 10 / 2014$ \\
28 & $26 / 06 / 2014$ & $26 / 07 / 2014$ & $25 / 08 / 2014$ & $23 / 09 / 2014$ & $23 / 10 / 2014$ \\
29 & $27 / 06 / 2014$ & $27 / 07 / 2014$ & $26 / 08 / 2014$ & $24 / 09 / 2014$ & $24 / 10 / 2014$ \\
30 & $28 / 06 / 2014$ & $28 / 07 / 2014$ & TIDAK ADA & $25 / 09 / 2014$ & $25 / 10 / 2014$ \\
& & & & & \\
Ijtim $\bar{a}^{\prime}$ & $27 / 06 / 2014$ & $27 / 07 / 2014$ & $25 / 08 / 2014$ & $24 / 09 / 2014$ & $24 / 10 / 2014$ \\
Jam & $15: 09$ & $05: 42$ & $21: 13$ & $13: 14$ & $04: 57$ \\
\hline
\end{tabular}

Tabel 3.

\section{Sistem Penanggalan Hijriyyah 1436H berdasar Kriteria 29}

\begin{tabular}{ccccccc} 
Tanggal & Zulhijah & Muharam & Safar & Rabi'ul I & Rabi'ul II & Jumadil I \\
\hline $\mathbf{1}$ & $26 / 09 / 2014$ & $26 / 10 / 2014$ & $24 / 11 / 2014$ & $24 / 12 / 2014$ & $22 / 01 / 2015$ & $20 / 02 / 2015$ \\
$\ldots$ & $\ldots$ & $\ldots$ & $\ldots$ & $\ldots$ & $\ldots$ & $\ldots$ \\
$\mathbf{2 9}$ & $24 / 10 / 2014$ & $23 / 11 / 2014$ & $22 / 12 / 2014$ & $21 / 01 / 2015$ & $19 / 02 / 2015$ & $20 / 03 / 2015$ \\
$\mathbf{3 0}$ & $25 / 10 / 2014$ & & $23 / 12 / 2014$ & & & $21 / 03 / 2015$ \\
& & & & & & \\
Ijtima' & $24 / 10 / 2014$ & $22 / 11 / 2014$ & $22 / 12 / 2014$ & $20 / 01 / 2015$ & $19 / 02 / 2015$ & $20 / 03 / 2015$ \\
& $4: 47$ & $19: 32$ & $8: 36$ & $20: 14$ & $6: 47$ & $16: 36$ \\
\hline & & & & & & \\
Tanggal & Jumadil II & Rajab & Sya'ban & Ramadhan & Syawal & Zulkaidah \\
\hline $\mathbf{1}$ & $22 / 03 / 2015$ & $20 / 04 / 2015$ & $20 / 05 / 2015$ & $18 / 06 / 2015$ & $18 / 07 / 2015$ & $16 / 08 / 2015$ \\
$\mathbf{2 .}$ & $\ldots$ & $\ldots$ & $\ldots$ & $\ldots$ & $\ldots$ \\
$\mathbf{2 9}$ & $19 / 04 / 2015$ & $18 / 05 / 2015$ & $17 / 06 / 2015$ & $16 / 07 / 2015$ & $15 / 08 / 2015$ & $13 / 09 / 2015$ \\
$\mathbf{3 0}$ & & $19 / 05 / 2015$ & & $17 / 07 / 2015$ & & $14 / 09 / 2015$ \\
& & & & & & \\
Ijtima' & $19 / 04 / 2015$ & $18 / 05 / 2015$ & $16 / 06 / 2015$ & $16 / 07 / 2015$ & $14 / 08 / 2015$ & $13 / 09 / 2015$ \\
& $1: 57$ & $11: 13$ & $21: 05$ & $8: 24$ & $21: 53$ & $13: 41$ \\
\hline
\end{tabular}

30Berdasarkan kriteria ijtim $\bar{a}^{\prime}$ yang dihitung dalam penanggalan Masehi. Tanggal 29 Syawal bertepatan dengan tanggal 26/08/2014 hal ini dikarenakan pada tanggal 25/08/2014 ijtimā' terjadi setelah Matahari terbenam.

218 || Volume 25, Nomor 2, Oktober 2015

AL-AHKAM — ISSN 0854-4603 


\section{Kesimpulan}

Dalam pandangan hisab, perhitungan mundur dengan Kriteria 29 ini juga dapat disebut sebagai kriteria wujudnya hiläl kamariah. Hiläl akan selalu wujud pada tanggal 29, sehingga tidak terdapat lagi istilah hilāl di bawah ufuk. Sebagaimana hisab pada umumnya, perhitungan dengan Kriteria 29 ini juga memberikan kepastian akan keteraturan sistem penanggalan Hijriyah.

Sedangkan dalam pandangan rukyat, dengan menetapkan tanggal 29 sebagai hari rukyat dengan syarat tampaknya hilāl, maka tidak akan terjadi kembali pelaksanaan ru'yat al-hilāl yang sia-sia. Seperti penetapan awal Ramadhan 1436H beberapa waktu lalu. Kegiatan rukyat dilaksanakan pada tanggal 16 Juni 2015, namun keberadaan hilāl tidak ada atau hilāl masih berada di bawah ufuk. Hal ini tentu berbeda dengan rukyat yang tidak berhasil melihat hilāl karena kondisi cuaca. Sebagus apapun kriteria penanggalan tetap tidak dapat memastikan akan keberhasilan ru'yat al-hilāl. Meski demikian, Kriteria 29 menjamin keberadaan obyek yang akan dilihat, yaitu hilāl.[a]

\section{DAFTAR PUSTAKA}

Azhari, Susiknan, Pembaharuan Pemikiran Hisab di Indonesia, Yogyakarta: Pustaka Pelajar, 2002.

Departemen Agama RI, 2009, Syaamil Al-Qur'an dan Terjemahnya, Bandung: Sygma Examedia Arkanleema.

Dershowitz, Nachum dan Edward M. Reingold, Calendrical Calculations, New York: Cambridge University Press, 1997.

Djamaluddin, Thomas, Menggagas Fiqih Astronomi, Bandung: Kaki Langit, 2005.

Fauzan, Ahmad, Melacak Algoritma Hisab Awal Bulan Qomariah dalam Kitab Nurul Anwar, Jurnal Penelitian, Vol. 11, No. 1, Mei 2004.

Fitriyani, Vivit, Penerapan Ilmu Astronomi Dalam Upaya Unifikasi Kalender Hijriyah di Indonesia, Makalah untuk Annual Conference on Islamic Studies (ACIS) ke-12 Tahun 2012 di Surabaya 
Hendro Setyanto \& Fahmi Fatwa Rosyadi Satria Hamdani

Grenville, G.S.P. Freeman, The Muslim and Christian Calendars, New York: Oxford University Press, 1963.

Hambali, Slamet, Pengantar Ilmu Falak: Menyimak Proses Pembentukan Alam Semesta, Banyuwangi: Bismillah Publisher, 2012.

Ilyas, Mohammad, Sistem Kalendar Islam dari Perspektif Astronomi, Kuala Lumpur: Dewan Bahasa dan Pustaka, 1997.

Izzuddin, Ahmad, Fiqih Hisab Rukyah: Menyatukan NU \& Muhammadiyah dalam Penentuan Awal Ramadhan, Idul Fitri, dan Idul Adha, Jakarta: Erlangga, 2007.

Jauharī, Ṭanțawi, al-Jawāhir fi Tafsìiri al-Qur'ān, juz 5, Mesir: Musțafā al-Bābī alHalbì, 1928.

Jauharī, Ṭanțawi, al-Jawāhir fi Tafsīiri al-Qur'ān, juz 6, Mesir: Musțafā al-Bābī alHalbì, 1928.

Jayusman, Isyarat Penentuan Awal Bulan Kamariah dalam al-Qur'an: Mencermati Perbedaan Kriteria dan Metode Penetapan Awal Bulan Kamariah di Indonesia, Jurnal al-Dzikra, Vol. 5, No. 09, Juli-Desember 2011.

Khazin, Muhyiddin, Ilmu Falak dalam Teori dan Praktik, Yogyakarta: Buana Pustaka, 2004.

Khazin, Muhyiddin, Kamus Ilmu Falak, Yogyakarta: Buana Pustaka, 2005.

Majelis Tarjih dan Tajdid Pengurus Pusat Muhammadiyah, 2009, Pedoman Hisab Muhammadiyah, Yogyakarta: Majelis Tarjih dan Tajdid PP Muhammadiyah.

Muslim, Abī Husain, Sahịhh Muslim, Riyadh: Dār al-Ṭayyibah, 2006

Nashirudin, Muh., Kalender Hijriyah Universal: Kajian atas Sistem dan Prospeknya di Indonesia, Semarang: El-Wafa, 2013.

Rohmat, Penentuan Awal Bulan Qamariyah menurut Muhammadiyah, Jurnal Ijtimaiyya, Vol. 7, No. 1, Februari 2014. 